\title{
Structural and functional aspects of cultured epididymal epithelial cells isolated from pubertal rats
}

\author{
M. G. White, Y.-S. Huang*, Laura L. Tres and A. L. Kierszenbaum \\ Department of Anatomy, Laboratories for Reproductive Biology, and \\ *The Cancer Research Center, School of Medicine, University of North Carolina at \\ Chapel Hill, Chapel Hill, North Carolina 27514, U.S.A.
}

\begin{abstract}
Summary. Acidic epididymal glycoprotein (AEG) and androgen-binding protein (ABP) antisera were used to study functional activities of primary cell cultures of the epididymal epithelium of 20-23-day-old rats. Extensive AEG immunoreactivity was associated with almost all epithelial cells of the distal caput, corpus and cauda epididymidis. ABP immunoreactivity was solely confined to some epithelial cells of the caput epididymidis. AEG and ABP immunoreactive cells were identified as principal cells. Morphological studies of enzymically dispersed aggregates of the epididymal epithelial cells showed that stromal cells were satisfactorily removed and that cell aggregates consisted of a predominant population of cells displaying the morphological characteristics of principal cells. Scanning and transmission electron microscopic studies of cultured epididymal epithelial cells in monolayers demonstrated that microvilli and pit-like invaginations of the cell surface were preserved during the first 7-10 days of culture and then gradually disappeared. Other characteristic subcellular structures such as Golgi apparatus and rough endoplasmic reticulum cisterna were preserved. Electrophoretic analysis of $\left[{ }^{35} \mathrm{~S} \mid\right.$ methioninelabelled secretory polypeptides released by epididymal epithelial cells into the culture medium demonstrated a distinct protein band pattern which differed from that observed in the medium of cultured rat Sertoli cells. These results demonstrate that primary cultures of epididymal epithelial cells isolated from sexually immature rats maintain several differentiated characteristics of the intact organ and therefore provide a valuable system for the study of epididymal epithelial cell function.
\end{abstract}

\section{Introduction}

The epididymis provides an environment for post-testicular maturation of spermatozoa (for reviews see Bedford, 1975; Hamilton, 1975; Turner, 1979). This environment is the result of specialized absorptive and secretory functions confined to the androgen-dependent epithelium of the epididymal duct. Some of the products secreted by epididymal epithelial cells interact with spermatozoa during their passage through the epididymis and facilitate the development of motility and acquisition of fertilizing capacity of the male gamete (Bedford, 1975). The available experimental data have shown that androgen-binding protein (ABP), a specific Sertoli cell secretory protein, is transported to the epididymis as an androgen-protein complex (French \& Ritzen, 1973). It has been suggested that ABP supplies androgens for the maintenance of the epididymal structure and function (Tindall et al., 1974; Danzo, Cooper \& Orgebin-Crist, 1977; 
Purvis \& Hansson, 1978). Another protein present in the rat epididymal fluid, acidic-epididymal glycoprotein (AEG, molecular weight 32 000) (Lea, Petrusz \& French, 1978) has been identified as a secretory product of principal cells. Principal cells are the predominant cell type of the rat epididymal epithelium (Hamilton, 1975) which also contains clear cells, apical cells, basal cells and 'halo cells'.

A primary cell culture system consisting of epididymal epithelial cells may express functions of the epididymal epithelium as they occur in the intact organ and, thus, provide a system for experimentation. We have previously reported a cell isolation and culture procedure of enzymically dissociated epididymal epithelial cells from pubertal and sexually mature rats (Kierszenbaum, Lea, Petrusz, French \& Tres, 1981a). In the present study our attention has been devoted to the culture of epithelial cells isolated from the epididymis of pubertal rats $(20-23$ days old).

\section{Materials and Methods}

\section{Preparation of cultures}

Primary cultures of rat epididymal epithelial cells. A complete description of the method has been reported (Kierszenbaum et al., 1981a). Briefly, epididymides of 20-23-day-old rats (Charles River $C D$ ) were removed aseptically and dissected free of fat, connective tissue and blood vessels. During the 15-min interval required for removal of epididymides and separation of caput, corpus and cauda segments, each epididymis was placed in Hanks' Balanced Salt Solution (HBSS). Epididymal segments were cut into small pieces $(2 \mathrm{~mm}$ or less) and dissociated with $0.25 \%$ trypsin in $\mathrm{HBSS}$ at $32^{\circ} \mathrm{C}$ for $30 \mathrm{~min}$ with continuous agitation. The resulting sample was centrifuged $(800 \mathrm{~g}, 5 \mathrm{~min})$, the supernatant discarded and the pellet was suspended in a solution of collagenase ( $1 \mathrm{mg} / \mathrm{ml} \mathrm{HBSS}$ ) and incubated at $32^{\circ} \mathrm{C}$ for $60-75 \mathrm{~min}$. The sample was allowed to stand at room temperature for $5 \mathrm{~min}$, the supernatant was discarded and the resulting sediment containing traces of collagenase was suspended in Eagle's minimum essential medium (Gibco, Grand Island, NY) supplemented with non-essential amino acids $(0 \cdot 1 \mathrm{~mm})$, sodium pyruvate $(1 \mathrm{mM})$, glutamine $(4 \mathrm{mM}), 5 \alpha$-dihydrotestosterone $\left(10^{-9} \mathrm{M}\right), 10 \%(\mathrm{v} / \mathrm{v})$ fetal bovine serum, penicillin $(100 \mathrm{U} / \mathrm{ml})$ and streptomycin $(100 \mu \mathrm{l} / \mathrm{ml})$. The sample consisting mainly of aggregates of epithelial cells was plated in tissue culture flasks or on coverslips and incubated in a humidified $\mathrm{CO}_{2}$-air incubator at $32^{\circ} \mathrm{C}$. Samples taken after treatment with trypsin or collagenase were processed for transmission electron microscopy (see below) to monitor enzymic action.

Primary cultures of rat Sertoli cells. Testes from the same animals used for epididymal epithelial cell cultures were removed for establishing Sertoli cell primary cultures. The cell isolation and culture procedure were based on the method of Dorrington \& Fritz (1975), slightly modified (Kierszenbaum \& Tres, 1981), and the immunocytochemical characterization of ABP immunoreactive rat Sertoli cells were as described by Kierszenbaum et al. (1980).

\section{Immunohistochemical localization of $A E G$ and $A B P$ in intact epididymides}

Whole epididymides were fixed in $4 \%$ paraformaldehyde in phosphate buffer $(\mathrm{pH} 7.4)$. The tissue was then dehydrated to dimethoxypropane (Maser \& Trimble, 1977) and transferred to xylene for infiltration and paraffin-wax embedding. Sections $(5 \mu \mathrm{m}$ thick) were processed for immunoperoxidase staining according to the technique of Petrusz, DiMeo, Ordronneau, Weaver \& Keefer (1975). Method specificity was tested by staining with increasing dilutions of anti-AEG and anti-ABP sera generated in rabbits. Satisfactory staining was obtained with 1:1000$1: 10000$ dilutions. No staining was detected at dilutions of $1: 100000$ or higher. Antibody specificity was tested by observing the absence of staining after absorbing anti-AEG serum with 
purified AEG (Lea et al., 1978). Anti-ABP serum absorption with purified ABP or epididymal cytosol significantly reduced staining (Kierszenbaum et al., 1980; Feldman et al., 1981). AEG and $А B P$ antibodies were evaluated by immunodiffusion, immunoelectrophoresis and radioimmunoassay as previously reported (AEG; Lea et al., 1978; ABP: Feldman et al., 1981).

\section{Terminology}

According to Sun \& Flickinger (1979), the intact epididymal epithelium of 16-28-day-old rats consists of two cell types: a predominant cell type descriptively termed columnar cell and sparse narrow cells. By Day 28, columnar cells develop into principal cells and basal cells. Narrow cells may persist as such in the initial segment of the epididymis or differentiate into light (clear) cells in the corpus and cauda epididymidis of the adult rat. Because of the functional and morphological features described in 'Results', columnar and narrow cells observed in the epididymis of 20-23-day-old rats are designated in this paper as principal cells.

\section{Microscopy}

Scanning electron microscopy. Epididymal epithelial cells were seeded on round plastic coverslips (13 mm in diameter; Thermanox-Lux Scientific Co., Newbury Park, California) at a cell density of about $2 \times 10^{3}$ cells/coverslip and cultured in $60-\mathrm{mm}$ plastic culture dishes. Cells were fixed in tannic acid-osmium tetroxide according to the technique of Murakami (1978) followed by dehydration in dimethoxypropane (Maser \& Trimble, 1977). Specimens were dried in a critical point drying apparatus using $\mathrm{CO}_{2}$ as a transitional fluid. After drying, specimens were coated with platinum-palladium in a sputter coater and examined with a JSM-35 scanning electron microscope at an accelerating voltage of $25 \mathrm{kV}$.

Transmission electron microscopy. Epididymal epithelial cells cultured on plastic coverslips $(9 \times 35 \mathrm{~mm}$, Thermanox) were rinsed in phosphate buffered saline and fixed in $2.5 \%$ glutaraldehyde in $0.1 \mathrm{M}$-phosphate buffer ( $\mathrm{pH} \mathrm{6.9)}$ for $1 \mathrm{~h}$ at room temperature. Specimens were postfixed in $1 \%$ osmium tetroxide, embedded in epoxy resin (Maraglas: Polysciences Inc., Warrington, PA) and sectioned with orientations parallel or perpendicular to the substrate. After trypsin and collagenase treatments samples were fixed and embedded as described above. Thick sections $(1 \mu \mathrm{m})$ were stained with toluidine blue $O$. Thin sections were stained with uranyl acetate and lead citrate. Sections were examined with a JEM 100B electron microscope operated at an accelerating voltage of $60 \mathrm{kV}$.

\section{Sodium dodecyl sulphate-polyacrylamide gel electrophoresis}

Protein synthesis and secretion of rat epididymal epithelial cell cultures established from whole epididymides in tissue culture flasks (cell density: $1 \times 10^{4}$ cells $/ \mathrm{ml}$ ) were studied with denaturing gel electrophoresis. Electrophoretic patterns of proteins in preparations of epididymal epithelial cells and media were compared with those of cultured rat Sertoli cells obtained from the same animal. After 5-7 days of culture and before labelling with $\left[{ }^{35} S\right]$ methionine $(75 \mu \mathrm{Ci} / \mathrm{ml} ; \mathrm{sp}$. act. $900-1200 \mathrm{Ci} / \mathrm{mmol}: \mathrm{L}-\left[{ }^{35} \mathrm{~S}\right]$ methionine containing $0 \cdot 1 \%$ 2-mercaptoethanol: Amersham, Arlington Heights, Illinois, U.S.A.), cells were exposed to a serum-free, hormone-free, low-methionine $(1 / 10)$ Eagle's minimum essential medium for 5-12 h. Cultures were labelled with $\left[{ }^{35} \mathrm{~S}\right]$ methionine for $2 \mathrm{~h}$ (epididymal cultures) and 5-6 h (Sertoli cell cultures). Media were collected and centrifuged at $1000 \mathrm{~g}$ for $10 \mathrm{~min}$ to remove cells that became detached from the substrate. Proteins in media were precipitated with $10 \%$ trichloroacetic acid (TCA). After $30 \mathrm{~min}$ incubation in ice, media were centrifuged at $12000 \mathrm{~g}$ for $10 \mathrm{~min}$ and the pellet was rinsed with acetone $\left(-20^{\circ} \mathrm{C}\right)$ to remove residual TCA. Then $50 \mu \mathrm{l}$ of the sample buffer $(0.025 \mathrm{M}$-Tris- $\mathrm{HCl}$, pH 6.8; $2 \%$ sodium dodecyl sulphate (SDS); 5\% 2-mercaptoethanol; $10 \%$ glycerol; $0.05 \%$ bromophenol blue) were added to dissolve precipitated protein samples. 
Cells (epididymal epithelial cells or Sertoli cells) were rinsed twice with cold phosphatebuffered saline, collected by scraping the substrate with a silicone rubber blade in $0.15 \% \mathrm{NaCl}$,

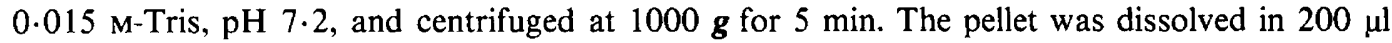
sample buffer and sonicated for $1 \mathrm{~min}$. Aliquots of $30 \mu \mathrm{l}$ of the resulting sample were heated at $100^{\circ} \mathrm{C}$ for $2 \mathrm{~min}$. Samples were processed according to the method of Laemmli (1970) and Studier (1973) in continuous gradient slab gels $(16 \times 14 \mathrm{~cm})$ of $5-15 \%$ acrylamide with $0 \cdot 1 \%$ SDS. A stacking gel of $3.5 \%$ acrylamide was cast above the resolving gradient gel. After electrophoresis, the gels were stained overnight in $0.1 \%$ Coomassie brilliant blue in $10 \%$ acetic acid and $50 \%$ methanol and destained in $10 \%$ acetic acid. Detection of the resolved

\section{PLATE 1}

Fig. 1. Immunohistochemical localization of AEG in whole epididymis of a 23-day-old rat. At this magnification, the AEG immunoreactive epididymal epithelium appears as densely stained rings of variable diameter. While the initial segment (IS) and proximal caput are devoid of AEG staining, the distal caput (Cap), corpus (Cor) and cauda (Cau) segments depict AEG immunoreactivity.

Fig. 2. Cross-section of the epididymal duct at the middle caput region. Immunoreactive AEG is observed in narrow (arrowheads) and columnar (dark staining) cells. AEG immunoreactivity is associated with an increasing number of epithelial cells in duct segments distal to the testis (direction of the arrow). Note the lack of AEG staining in the lumen. $\times 290$.

Fig. 3. Cross-section of the epididymal duct at the caput region. Immunoreactive ABP (dark staining) is observed in the perinuclear and apical (arrowheads) region of some of the epithelial cells. A less conspicuous ABP staining is observed in the lumen (small dark granules) associated with microvilli (stereocilia). $\times 1100$.

Fig. 4. Section of the epididymal duct (caput region) displaying columnar and narrow (arrowheads) epithelial cells. The wall of the duct displays 2 or 3 layers of smooth muscle cells. The arrow indicates a migrating leucocyte. Fixed in $2.5 \%$ glutaraldehyde and embedded in glycol-methacrylate, $1 \mu \mathrm{m}$ section stained with methylene blue, 22-day-old rat. $\times 380$.

Figs 5 and 6. Photomicrographs of longitudinal (Fig. 5) and cross-sections (Fig. 6) of epididymal tissue fixed in glutaraldehyde after 75 min of collagenase digestion as described in 'Materials and Methods'. The stroma has been removed and the epididymal epithelial cells remain attached to one another. Some cytoplasmic vacuolization is observed. Toluidine blue, $1 \mu \mathrm{m}$ sections, Maraglas embedded: Fig. 5, ×680; Fig. 6, 640.

Fig. 7. Transmission electron micrograph of an epididymal epithelial cell aggregate after enzymic removal of stromal elements (pellet specimen, see 'Materials and Methods'). The lumen displays many microvilli projecting from the epithelial cells. Leucocytes (L), also called 'halo cells', can be observed among the epithelial cells.

\section{PLATE 2}

Fig. 8. Transmission electron micrograph of an epididymal epithelial cell aggregate after trypsin-collagenase digestion. The arrows indicate densities between adjacent cells which at high magnification (not shown) correspond to tight junctions. The luminal region of the cells displays a few microvilli (Mv). The opposite region (basal region) is devoid of stromal elements. L, migrating leucocyte or 'halo cell'. $\times 1830$.

Fig. 9. Transmission electron micrograph of a supernatant specimen after collagenase digestion (see 'Materials and Methods'). Most of these cells are smooth muscle cells which, at high magnification (not shown), depict abundant microfilaments. $\times 4920$.

Fig. 10. Phase-contrast micrograph of epididymal epithelial cells isolated from the caput region. The asterisk indicates the primary cell aggregate. Cells at the bottom form an epithelial-like arrangement spreading out from the primary aggregate. $29 \mathrm{~h}$ after plating. $\times 830$.

Fig. 11. Photograph of cultured epididymal epithelial cells isolated from whole epididymis and obtained in a modulation contrast microscope (Hoffman, 1977). The three-dimensional appearance of living epididymal epithelial cells yields edge details of the cell nucleus $(N)$ and nucleolus. The cytoplasm displays vesicles $(\mathrm{V})$ and small granules. 3 days after plating. $\times 655$. 
PLATE 1

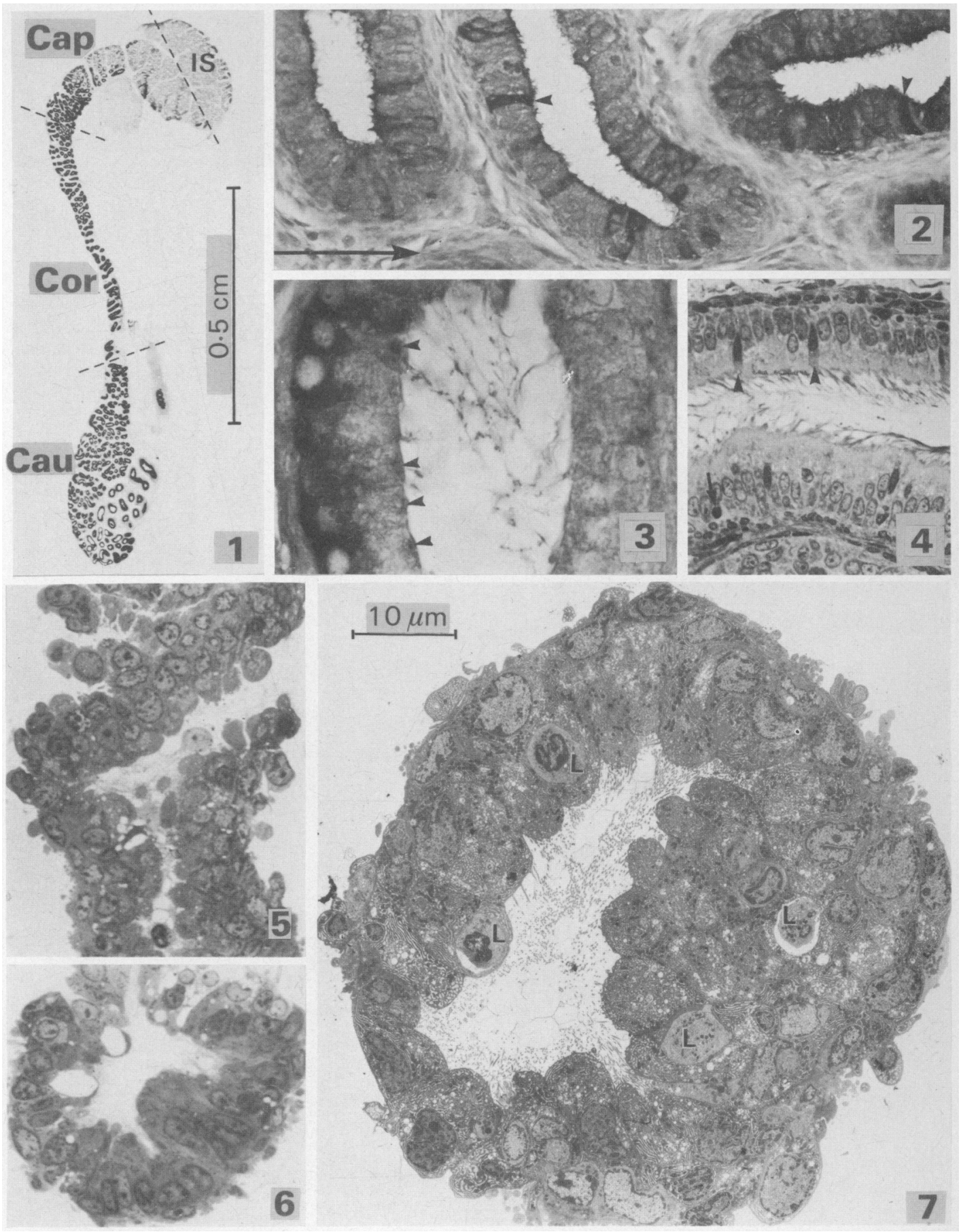


PLATE 2

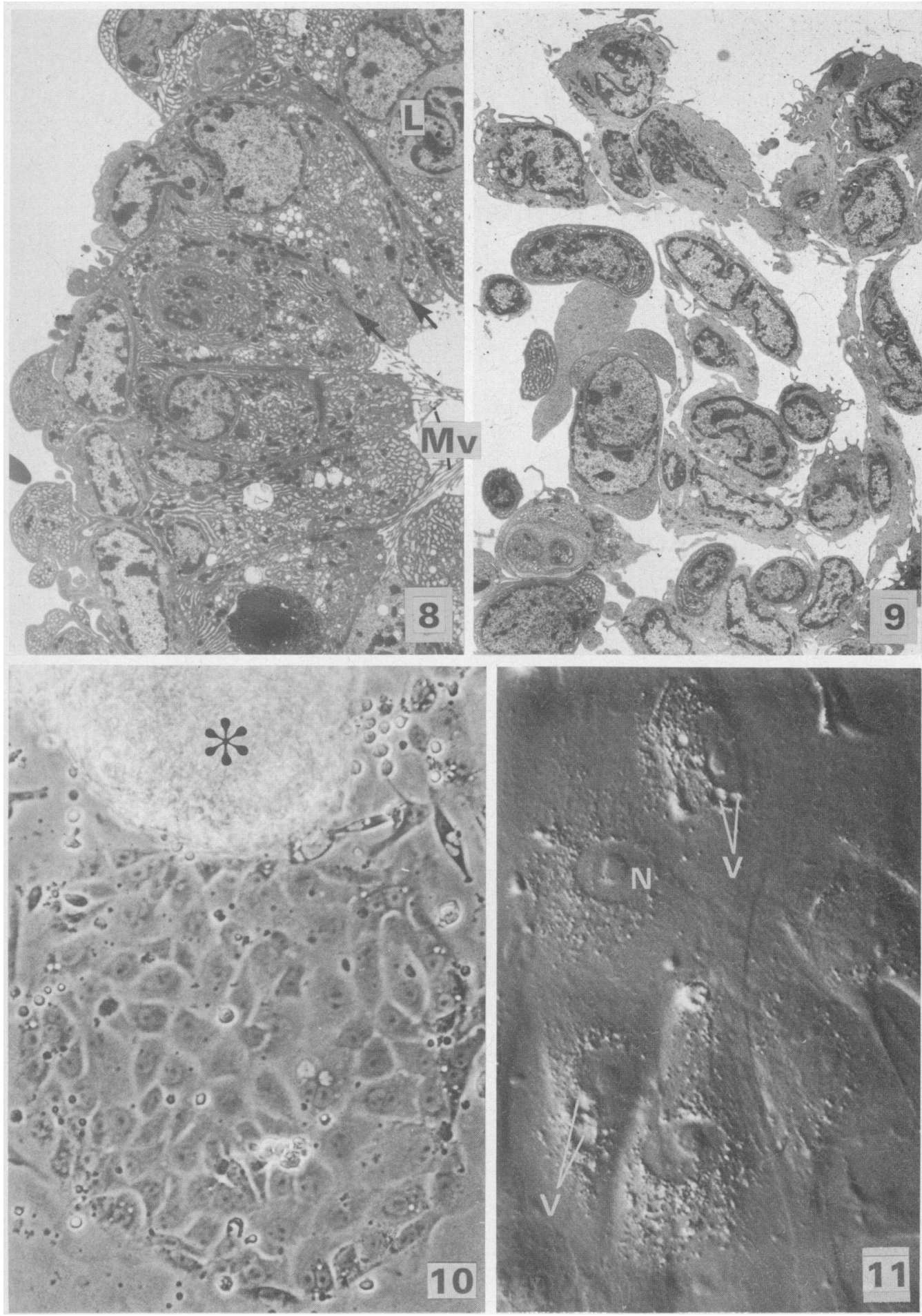


PLATH: 3
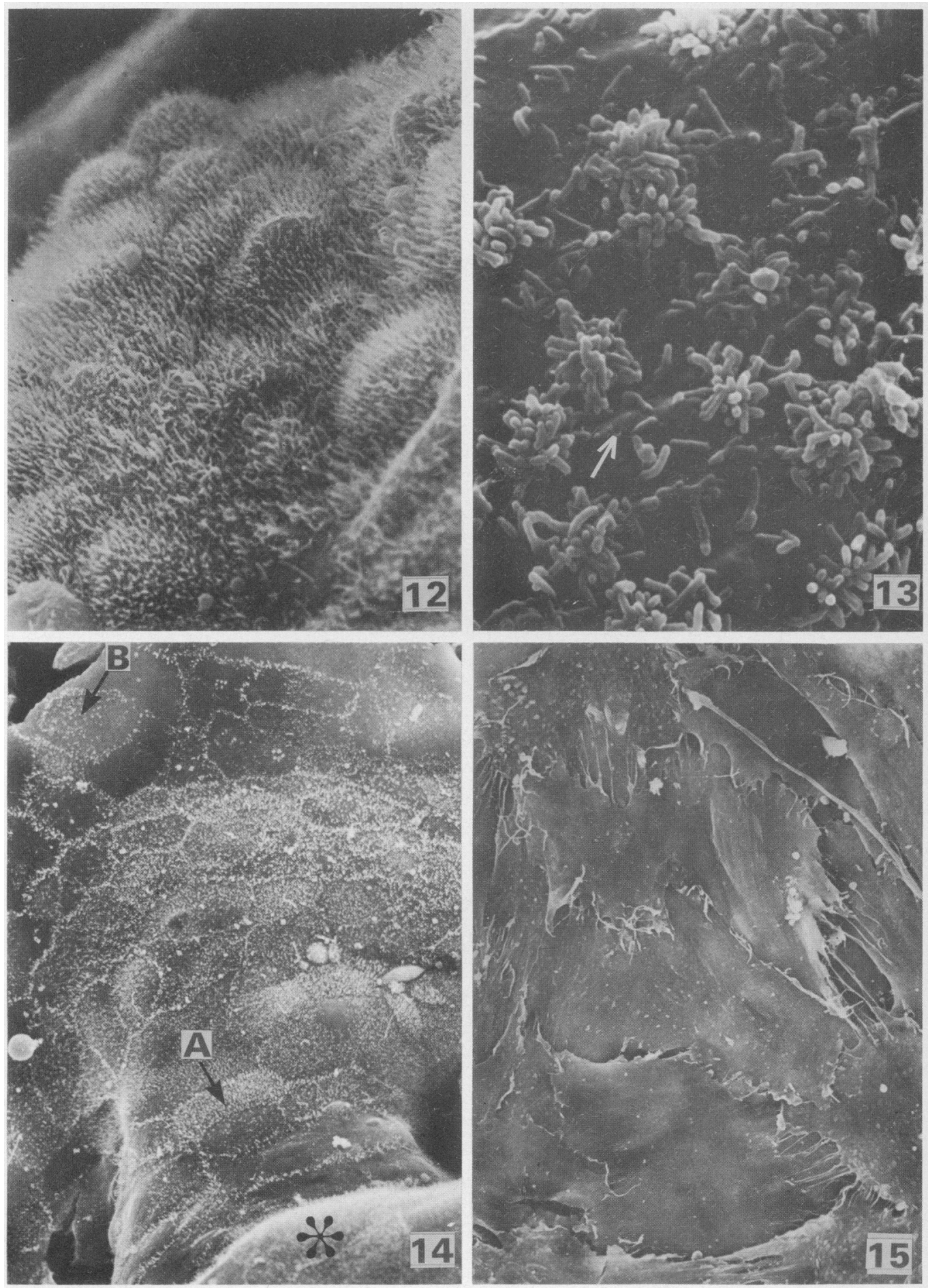

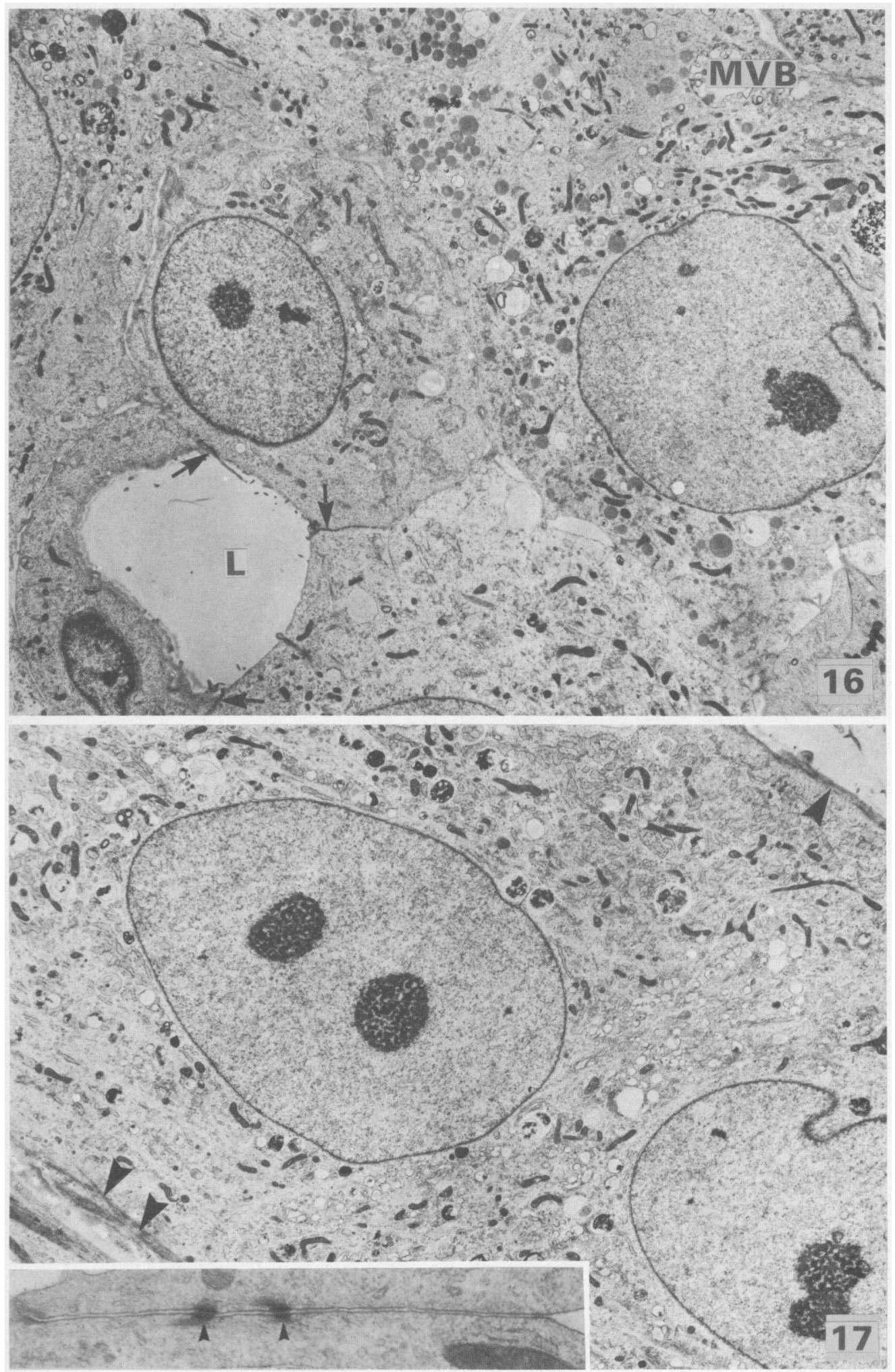


\section{PLATE 5}

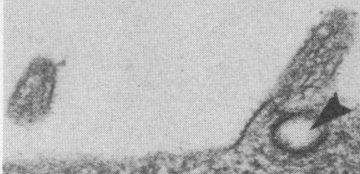

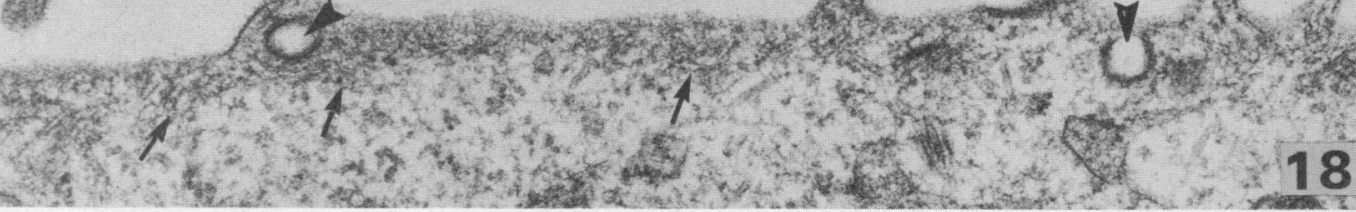

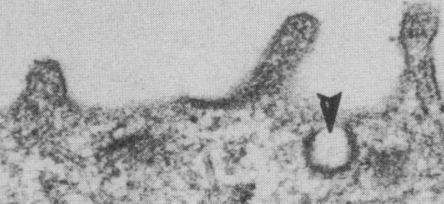

(4) (2)
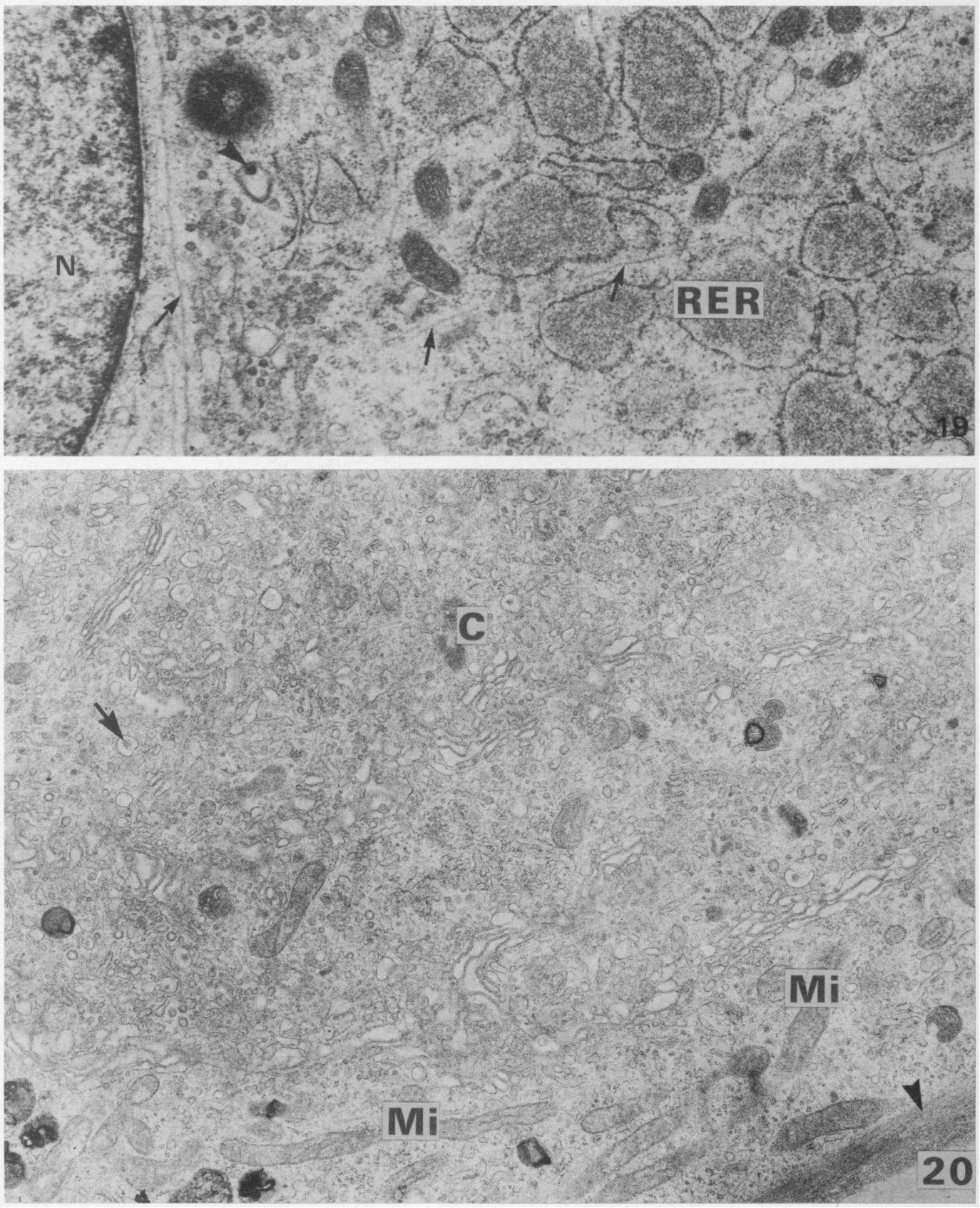
PLATE 6

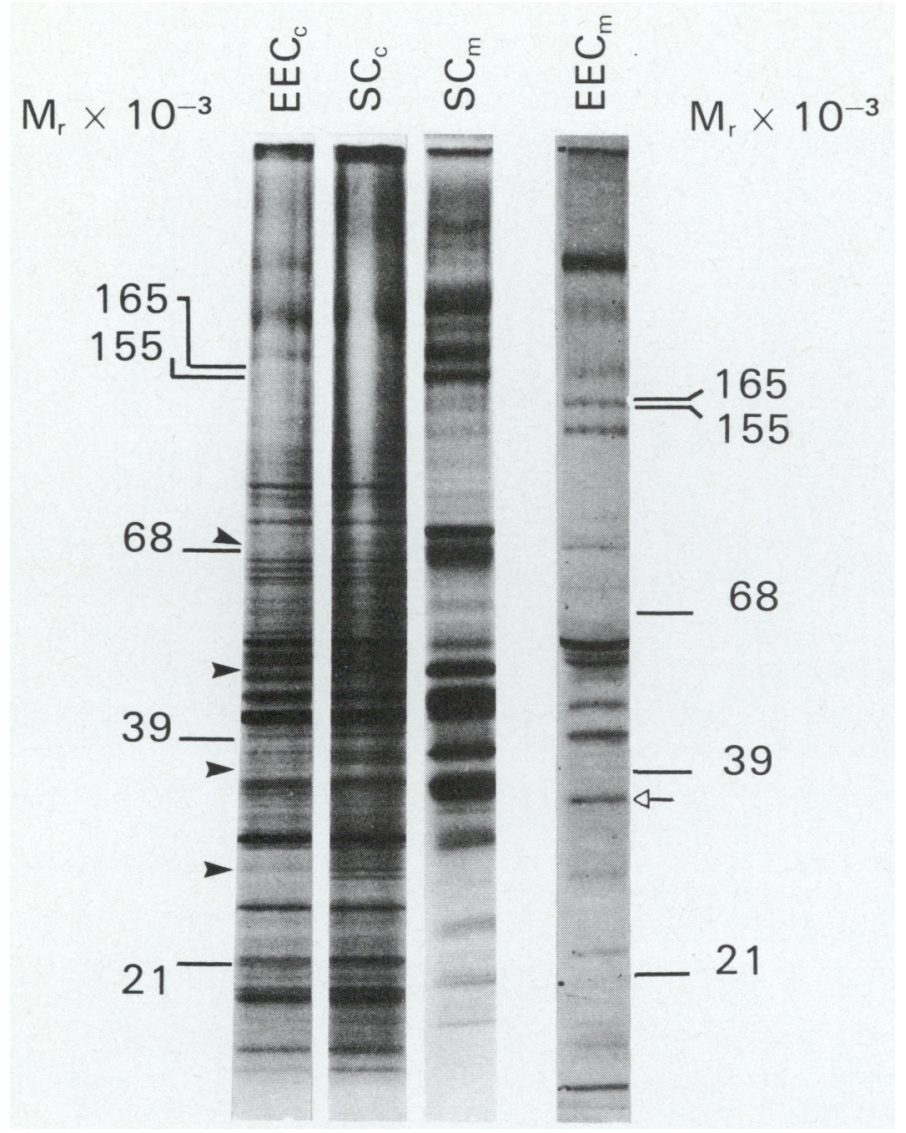




\section{PLATE 3}

Fig. 12. Scanning electron micrograph of an aggregate of epididymal epithelial cells isolated from caput epididymidis. Multiple long microvilli project out from the convex cell surface. $48 \mathrm{~h}$ of culture. $\times 2570$.

Fig. 13. Scanning electron micrograph of cultured epididymal epithelial cells displaying clustered microvilli. The arrow indicates a pit-like invagination of the cell surface (compare with Fig. 18). 3 days after plating. $\times 8550$.

Fig. 14. Scanning electron micrograph of a primary culture of epididymal epithelial cells isolated from whole epididymis. The primary epididymal epithelial aggregate $\left(^{*}\right)$ attached to the substrate and formed a discrete cluster of cells. Cells have coalesced and organized an epithelial-like growth pattern. A variation in the number of microvilli can be observed in cell A (close to the primary cell aggregate) and cell $B$ (distal to the aggregate). $\times 520$.

Fig. 15. Scanning electron micrograph of a culture of epididymal epithelial cells isolated from whole epididymis. The cell surface is predominantly smooth. 30 days after plating. $\times 2170$.

\section{PLATE 4}

Fig. 16. Transmission electron micrograph of epithelial cells isolated from whole epididymis, cultured for $72 \mathrm{~h}$. A small lumen (L) is limited by cells held together by structures (arrows) identified at high magnification as junctional complexes (not shown). Mitochondria, dense granules and a multivesicular body (MVB) can be seen in the cytoplasm. Specimen sectioned parallel to the culture substrate. $\times 7750$.

Fig. 17. Epididymal epithelial cells isolated from whole epididymis, cultured for $96 \mathrm{~h}$. The arrowheads indicate bundles of microfilaments aligned under the cell membrane. Nuclear and cytoplasmic organelles are comparable to those illustrated in Fig. 16. $\times 9240$. Inset: Two desmosomes (arrowheads) between adjacent cells. Sectioned through a plane perpendicular to the culture substrate. $\times 23000$.

\section{PLATE 5}

Fig. 18. Transmission electron micrograph of an epididymal epithelial cell cultured for 7 days. The arrowheads indicate coated pits. Microfilaments in a random array (arrows) are observed under the cell membrane. Microvilli are short. Specimen sectioned perpendicular to the culture substrate. $\times 50100$.

Fig. 19. Detail of the cytoplasm of a cultured epididymal epithelial cell. Cisternae of the rough endoplasmic reticulum contain protein product. The arrowhead points to a dense granule inside a vesicle. A few microtubules can be identified in the cytoplasm (arrows). N, nucleus. Cultured for 6 days. Sectioned parallel to the substrate. $\times 35000$.

Fig. 20. Cytoplasmic portion of an epididymal epithelial cell isolated from caput epididymidis. Cultured for 2 months. The arrowhead indicates a peripheral bundle of microfilaments. The Golgi apparatus is extensively developed in this cell. Some of the vesicles contain a centrally-located granule (arrow). Mi, mitochondria. C, centriole. Specimen sectioned parallel to the culture substrate. $\times 11800$.

\section{PLATE 6}

Fig. 21. Autoradiogram of $\left[{ }^{35} \mathrm{~S}\right]$ methionine-labelled proteins from cell (c) and medium (m) samples of Sertoli cells (SC) and epididymal epithelial cells (EEC) (whole epididymis). Cell cultures were labelled 5-7 days after plating. Each track contained 35000 c.p.m. The arrowheads at the EECc track indicate regions in the track where differences exist with respect to $\mathrm{SCc}$ sample. The arrow indicates the position of a $32000 \mathrm{~mol}$. wt protein band in the EECm sample which presumably comigrates with AEG. Note the difference in electrophoretic patterns between $\mathrm{SCm}$ and EECm. 
$\left[{ }^{35} \mathrm{~S}\right]$ methionine-labelled proteins was achieved by drying the gel and exposing it to $\mathrm{X}$-ray film which then was developed. Estimates of molecular weight were determined by running standards of known molecular weight on the same gel (soybean trypsin inhibitor, 21000 ; bovine serum albumin, 68000 ; RNA polymerase subunits from $E$. coli: $\alpha$-subunit, $39000 ; \beta$-subunit, 155000 and $\beta^{\prime}$-subunit, 165000$)$. The incorporation of $\left[{ }^{35} S\right]$ methionine into cellular proteins was linear.

\section{Results}

\section{$A E G$ and $A B P$ immunoreactivity of the epididymal epithelium of pubertal rats}

Specific staining for AEG was observed in the epididymal epithelium of distal caput, corpus and cauda regions of 23-day-old rats (Pl. 1, Fig. 1). Most of the AEG Immunoreactivity was confined to the epithelial cells; there was little AEG immunoreactivity content in the lumen. AEG was located in the caput epididymidis in epithelial cells of the columnar and narrow type (PI. 1, Fig. 2). The luminal region of the epididymal epithelial cells displayed abundant long microvilli (stereocilia) showing strong immunoreactivity. AEG immunoperoxidase staining was extensive in the cytoplasm of epididymal epithelial cells of the distal caput (PI. 1, Fig. 2), corpus and cauda regions (Pl. 1, Fig. 1).

To determine whether ABP was transported towards the epididymal duct of pubertal rats, sections of the same epididymides as used for AEG staining were reacted with anti-ABP serum. ABP immunoreactivity was restricted to the caput epididymidis. Plate 1, Fig. 3, illustrates a cross-section of the epididymal duct from the caput region showing immunoreactive ABP associated in part with microvilli projecting into the lumen and with the perinuclear region of the epithelial cells.

\section{Microscopic evaluation of enzymically dissociated epididymal epithelia}

Light (Pl. 1, Figs 5 and 6) and electron microscopic (Pl. 1, Fig. 7) studies of rat epididymal duct minces after trypsin and collagenase digestion demonstrated that cellular components of the epididymal duct wall (smooth muscle cells) and interstitium (mainly fibroblasts and endothelial cells) were removed and remained in the supernatant (PI. 2, Fig. 9). After digestion, specimens of the epididymal epithelium retained the morphology and integrity typical of the intact tissue (Pl. 1, Fig. 7; Pl. 2, Fig. 8). Epididymal epithelial cells were identified as principal cells by the presence of long microvilli extending into the lumen and by the presence of a dilated vacuolar system representing Golgi and endoplasmic reticulum elements. "Halo cells", regarded as migrating leucocytes which infiltrate the epididymal epithelium (Hoffer, Hamilton \& Fawcett, 1973; Dym \& Romrell, 1975), were distinctly identified in the enzymically treated samples (Pl. 1, Fig. 7; Pl. 2, Fig. 8).

After plating, aggregates and single epididymal epithelial cells attached to the substrate and established a colony-like, epithelial-like growth pattern as monitored by phase-contrast microscopy (Pl. 2, Fig. 10; Kierszenbaum et al., 1981a), modulation contrast microscopy (Pl. 2, Fig. 11), scanning and transmission microscopy (see below).

\section{Scanning electron microscopy of cultured epididymal epithelial cells}

The morphological behaviour of epididymal epithelial cell aggregates in short- and long-term cultures was monitored by scanning electron microscopy. Epididymal epithelial cells isolated from caput and cauda epididymidis cultured for 48-72 $\mathrm{h}$ displayed long microvilli (average length: $2.8 \pm 0.40 \mu \mathrm{m}$ ) distributed randomly (Pl. 3, Fig. 12) or in a clumping, branching pattern (Pl. 3, Fig. 13). Pit-like invaginations of the cell surface were also observed (Pl. 3, Fig. 13). Long microvilli decreased in number with increasing time in culture (after $72 \mathrm{~h}$ ) as epididymal epithelial 
cells established a monolayer. Discrete clusters of epithelial cells showed both long and short microvilli (average length: $0.20 \pm 0.06 \mu \mathrm{m}$ ) sparsely distributed across the cell surface and at the intercellular border (Pl. 3, Fig. 14). Cells maintained broad areas of contact with adjoining cells, a feature which is characteristic of epithelial cells in culture (Pl. 3, Fig. 14). Epididymal epithelial cells cultured for about 30 days retained the epithelial-like pattern but were devoid of microvilli and pit-like invaginations (Pl. 3, Fig. 15). This finding was interpreted as a modification of the epididymal epithelial cell surface indicative of a possible decline of the absorptive function as cells adapted to culture conditions.

\section{Transmission electron microscopy of cultured epididymal epithelial cells}

When epididymal epithelial cells isolated from whole epididymides of 20-23-day-old rats were studied during the first 3 days of culture by transmission electron microscopy, it was possible to identify cell aggregates held together by junctional complexes, sometimes forming a small lumen (Pl. 4, Fig. 16). These cells were identified as primary explants of epididymal epithelial cells maintained in culture. After 3-4 days in culture, as cells adapted gradually to tissue culture conditions and formed a monolayer, it was possible to find an extensive network of filaments and microtubules throughout the cytoplasm (not shown). Microfilaments were arranged in thick bundles along the cell edges just under the cell membrane (Pl. 4, Fig. 17). Typical intercellular junctions (tight junctions and desmosomes) were observed between adjacent cells (P1. 4, Fig. 17, inset). Cultured cells also displayed abundant vesicles, dense granules, mitochondria, multivesicular bodies and endoplasmic reticulum cisternae (Pl. 4, Figs 16 and 17). Similar subcellular structures were observed in the samples of enzyme-treated epithelium (Pl. 1, Fig. 7; Pl. 2, Fig. 8).

The apical surface of epididymal epithelial cells examined 6-7 days after plating exhibited short microvilli and coated pits (P1. 5, Fig. 18) in agreement with scanning electron microscopic results (Pl. 3, Fig. 13). The cytoplasm of these cells contained discrete Golgi apparatus components and dilated rough endoplasmic reticulum cisternae with electron-dense contents (PI. 5, Fig. 19). Epididymal epithelial cells examined after 2 months in culture (Pl. 5, Fig. 20) showed structural features similar to those observed in short-term culture, including a Golgi apparatus consisting of stacks of fenestrated sacules and abundant vesicles. Some of the vesicles displayed a centrally located granule.

\section{Protein synthesis and secretion of cultured epididymal epithelial cells}

The electrophoretic protein band patterns observed in autoradiograms of $\left[{ }^{35} S\right]$ methioninelabelled samples were reproducible in several culture and labelling experiments and remained constant over an extended period of cell culture (up to 2 weeks). Cultured Sertoli cells were used to compare the electrophoretic patterns of $\left[{ }^{35} \mathrm{~S}\right]$ methionine-labelled proteins with those of epididymal epithelial cells in culture and determine cell-specific protein patterns. Whole cell homogenates of epididymal epithelial cells and Sertoli cells displayed protein band patterns which were similar although minor differences were noted (PI. 6, Fig. 21). However, the electrophoretic patterns obtained from media of cultured epididymal epithelial cells and Sertoli cells revealed differences. A characteristic protein band of molecular weight 32000 which presumably comigrated with AEG, was observed in the medium of cultured epididymal epithelial cells, in agreement with radioimmunoassay studies showing that AEG could be detected in the culture medium of these cells (Kierszenbaum et al., 1981a; Kierszenbaum, Petrusz, Lea, French \& Tres, 1981b).

\section{Discussion}

The present study describes immunohistochemical, electron microscopic and electrophoretic aspects of primary cultures of epididymal epithelial cells from caput, cauda and whole 
epididymides of pubertal rats. We have used these technical approaches (1) to determine the usefulness of epididymides of sexually-immature rats as a source of tissue for biological studies and (2) to validate the method by monitoring different steps of cell isolation and culture. Results from this and previous studies (Kierszenbaum et al., $1981 \mathrm{a}, \mathrm{b}$ ) demonstrate that the technique of isolation and culture of epididymal epithelial cells can be regarded as a useful approach for the study of functional activities of epididymal epithelial cells in culture. It can also complement procedures such as the culture of isolated epididymal tubular segments (Orgebin-Crist \& Tichenor, 1972; Blaquier, 1973) and the separation of homogeneous populations of viable epididymal cells by unit gravity sedimentation (Brooks, 1975; Killian, Snyder \& Amann, 1977). The epididymal epithelial cell culture system may also overcome limitations inherent to these two procedures (Kierszenbaum et al., 1981a).

The epididymis of pubertal rats displayed a well-defined anatomical localization of immunoreactive AEG associated with cells morphologically regarded as principal cells. ABP was also localized in the principal cells of the caput epididymidis. Therefore, we can assume that ABP is transported from the testis towards the epididymal duct of sexually immature rats. Principal cells are known to concentrate ABP in the caput epididymidis of sexually mature rats (Feldman et al., 1981). We therefore conclude that epithelial cells in culture established from epididymides of pubertal rats could provide a convenient model system for several experimental purposes, including a the study of AEG and ABP pathways and their regulatory mechanisms.

The microscopic screening of epithelial tissue obtained after enzymic digestion steps demonstrates: (i) an adequate removal of non-epithelial components of the epididymal wall and interstitium; (ii) the presence of a predominant population of cells with morphological characteristics of principal cells, and (iii) the integrity of the cell aggregates, as judged by electron microscopic criteria. The morphological preservation was correlated with cell viability determined by attachment of cell aggregates to the substrate after plating and further establishment of an epithelial-like growth pattern. It is possible that non-epithelial cells resulting from residual stromal elements may contaminate epididymal epithelial cell cultures. This possibility can be minimized by allowing the plated sample to settle in a tissue culture flask for about $6-12 \mathrm{~h}$. Under these conditions, non-epithelial cells attach very rapidly to the substrate leaving in suspension unattached epididymal epithelial cell aggregates which can then be transferred to a new culture flask or dish (Kierszenbaum et al., $1981 \mathrm{a}, \mathrm{b}$ ). Indeed, electron microscopic results of several isolation and culture experiments consistently demonstrated that most of the stromal elements of the epididymal duct were removed. Cultured epididymal epithelial cells show many features attributed to other epithelial cells in culture and non-epithelial cell contamination is rather insignificant.

Scanning electron microscopic results demonstrated the characteristic epithelial pattern of cultured epididymal epithelial cells. The numerous microvilli observed during the first week of culture shorten and gradually disappear until the cell surface becomes almost smooth. The loss of microvilli suggests that, as epididymal epithelial cells adapt to in-vitro conditions, they do not retain structures typical of the differentiated cell in vivo. However, as indicated above, the basic genetic and structural machinery required for the expression of the AEG gene and presumably other cell secretory products remains relatively intact. Epididymal epithelial cells other than principal cells could be present as contaminants in primary cell cultures and this possibility cannot be disregarded until specific biological markers become available for other epididymal epithelial cell types. Nonetheless, it is significant that, according to Sun \& Flickinger (1979), the epididymal epithelium of 20-23-day-old rats consists only of narrow and columnar cells. In our immunohistochemical preparations narrow and columnar cells were both AEG immunoreactive.

The epididymis absorbs fluid (Setchell, 1970) and ABP of testicular origin (French \& Ritzen, 1973; Danzo et al., 1977; Purvis \& Hansson, 1978; Feldman et al., 1981). It also secretes products which facilitate motility (Acott \& Hoskins, 1978), fertilizing capacity (Orgebin-Crist \& Jahad, 1978) and storage of spermatozoa (Jones, 1974). Interest in the characterization of 
specific epididymal secretory proteins stems from recent evidence showing that, as spermatozoa traverse the epididymal duct, they acquire a glycoprotein coat (Lea et al., 1978; Olson \& Hamilton, 1978; Kohane, Garberi, Cameo \& Blaquier, 1979; Voglmayr, Fairbanks, Jackowitz \& Colella, 1980; Olson \& Danzo, 1981). Jones, Brown, Von Glós \& Parker (1980) have reported that testosterone and factors present in testicular fluid regulate the synthesis of specific proteins in different regions of the rat epididymal duct.

Primary cultures of epididymal epithelial cells grown under conditions which allow gene expression in vitro identical to that responsible for function in vivo, could yield fundamental information concerning the role of secretory proteins in the post-testicular acquisition of fertilizing capacity by spermatozoa. Our present results show that epididymal epithelial cells in culture generate a distinct electrophoretic protein pattern which differs from that typical of cultured Sertoli cells. In the intact animal, the luminal fluid from proximal epididymal segments contains testicular proteins, some of Sertoli cell origin. A clear distinction between the corresponding secretory patterns of epididymal epithelial cells and Sertoli cells could facilitate further experimental studies in which products of these two culture systems could interact with each other and with spermatozoa in vitro.

This work was supported in part by NIH Grant HD-11884 and by a grant from World Health Organization (Project \#79063). We thank Dr Frank S. French for critical reading of the manuscript and for providing anti-ABP and anti-AEG sera; Dr Peter Petrusz for assistance with the immunohistochemistry; and Mr William McAllister for excellent photographic assistance.

\section{References}

Acott, T.S. \& Hoskins, D.D. (1978) Bovine sperm forward motility protein. Partial purification and characterization. J. biol. Chem. 253, 6744-6750.

Bedford, J.M. (1975) Maturation, transport and fate of spermatozoa in the epididymis. In Handbook of Physiology, Vol. 5; Endocrinology, pp. 303-317. Eds D. W. Hamilton \& R. O. Greep. American Physiological Society, Washington, D.C.

Blaquier, J.A. (1973) An in-vitro action of androgens on protein synthesis by epididymal tubules maintained in organ culture. Biochem. Biophys. Res. Commun. 52, 1177-1183.

Brooks, D. (1975) The isolation of epithelial cells from the rat epididymis. Andrologia 7, 241-253.

Danzo, B.J., Cooper, T.G. \& Orgebin-Crist, M.-C. (1977) Androgen binding protein (ABP) in fluids collected from the rete testis and cauda epididymidis of sexually mature and immature rabbits and observations on morphological changes in the epididymis following ligation of the ductuli efferentes. Biol. Reprod. 17, 64-77.

Dorrington, J.H. \& Fritz, I.B. (1975) Cellular localization of $5 \alpha$-reductase and $3 \alpha$-hydroxysteroid dehydrogenase in the seminiferous tubule of the rat testis. Endocrinology 96, 879-889.

Dym, M. \& Romrell, L.J. (1975) Intraepithelial lymphocytes in the male reproductive tract of rats and rhesus monkeys. J. Reprod. Fert. 42, 1-7.

Feldman, M., Lea, O.A., Petrusz, P., Tres, L.L., Kierszenbaum, A.L. \& French, F.S. (1981) Androgen-binding protein. Purification from rat epididymis, characterization, and immunocytochemical localization. J. biol. Chem. 256, 51705175 .
French, F.S. \& Ritzen, E.M. (1973) A high affinity androgen-binding protein (ABP) in rat testis. Evidence for secretion into efferent duct fluid and absorption by the epididymis. Endocrinology 93, $88-95$.

Hamilton, D.W. (1975) Structure and function of the epithelium lining the ductuli efferentes, ductus epididymidis and ductus deferens in the rat. In Handbook of Physiology, Vol. 5; Endocrinology, pp. 259-302. Eds D. W. Hamilton \& R. O. Greep. American Physiological Society, Washington, D.C.

Hoffman, R. (1977) The modulation contrast microscope: principles and performance. J. Microscopie 110, 205-222.

Hoffer, A.P., Hamilton, D.W. \& Fawcett, D.W. (1973) The ultrastructure of the principal cells and intraepithelial leucocytes in the initial segment of the rat epididymis. Anat. Rec. 175, 169-202.

Jones, R. (1974) Absorption and secretion in the cauda epididymidis of the rabbit and the effects of degenerating spermatozoa on epididymal plasma after castration. J. Endocr. 63, 157-165.

Jones, R., Brown, C.R., Von Glós, K.I. \& Parker, M.G. (1980) Hormonal regulation of protein synthesis in the rat epididymis. Characterization of androgen dependent and testicular fluid dependent proteins. Biochem.J. 188, 667-676.

Kierszenbaum, A.L. \& Tres, L.L. (1981) The structural and functional cycle of Sertoli cells in culture. In Bioregulators of Reproduction, pp. 207-228. Eds G. Jagiello \& H. J. Vogel. Academic Press, New York.

Kierszenbaum, A.L., Feldman, M., Lea, O., Spruill, W.A., Tres, L.L., Petrusz, P. \& French, F.S. (1980) Localization of androgen-binding protein in pro- 
liferating Sertoli cells in culture. Proc. natn. Acad. Sci. U.S.A. 77, 5322-5328.

Kierszenbaum, A.L., Lea, O., Petrusz, P., French, F.S. \& Tres, L.L. (1981a) Isolation, culture and immunocytochemical characterization of epididymal epithelial cells from pubertal and adult rats. Proc. natn. Acad. Sci. U.S.A. 78, 1675-1679.

Kierszenbaum, A.L., Petrusz, P., Lea, O., French, F.S. \& Tres, L.L. (1981b) Acidic epididymal glycoprotein in primary epithelial cell cultures of caput, corpus and cauda epididymis. J. Cell Biol. 91, 190a, Abstr.

Killian, G.J., Snyder, J. \& Amann, R.P. (1977) Unit gravity sedimentation separation of cells comprising the caput epididymis of the rat. Cell Tiss. Res. 183, $371-378$.

Kohane, A.C., Garberi, J.C., Cameo, M.S. \& Blaquier, J.A. (1979) Quantitative determination of specific proteins in rat epididymis. J. Steroid Biochem. 11, $671-674$.

Laemmli, U.K. (1970) Cleavage of structural proteins during the assembly of the head of bacteriophage T4. Nature, Lond. 227, 680-685.

Lea, O.A., Petrusz, P. \& French, F.S. (1978) Purification and localization of acidic epididymal glycoprotein (AEG): a sperm coating protein secreted by the rat epididymis. Int. J. Androl., Suppl. 2, 592-607.

Maser, M.D. \& Trimble, J.J. (1977) Rapid chemical dehydration of biological samples for scanning electron microscopy using 2,2-dimethoxypropane. $J$. Histochem. Cytochem. 25, 247-251.

Murakami, T. (1978) Tannin-osmium conductive staining of biological specimens for non-coated scanning electron microscopy. Scanning 1, 127-129.

Olson, G.E. \& Danzo, B.J. (1981) Surface changes in rat spermatozoa during epididymal transit. Biol. Reprod. 24, 431-443.

Olson, G.E. \& Hamilton, D.W. (1978) Characterization of the surface glycoproteins of rat spermatozoa. Biol. Reprod. 19, 26-35.
Orgebin-Crist, M.-C. \& Jahad, N. (1978) The maturation of rabbit epididymal spermatozoa in organ culture: inhibition by antiandrogens and inhibitors to ribonucleic acid and protein synthesis. Endocrinology 103, 46-53.

Orgebin-Crist, M.-C. \& Tichenor, P. (1972) A technique for studying sperm maturation in vitro. Nature, Lond. 239, 227-228.

Petrusz, P., DiMeo, P., Ordronneau, P., Weaver, C. \& Keefer, D.A. (1975) Improved immunoglobulinenzyme bridge method for light microscopic demonstration of hormone-containing cells of the rat adenohypophysis. Histochemistry 46, 9-26.

Purvis, K. \& Hansson, V. (1978) Androgens and androgen-binding protein in the rat epididymis. $J$. Reprod. Fert. 52, 59-63.

Setchell, B.P. (1970) Testicular blood supply, lymphatic drainage, and secretion of fluid. In The Testis, Vol. I, pp. 101-239. Eds A. D. Johnson, W. R. Gomes \& N. L. VanDemark. Academic Press, New York.

Studier, W.F. (1973) Analysis of bacteriophage T7 early RNAs and proteins on slab gels. J. molec. Biol. 79, 237-248.

Sun, E.L. \& Flickinger, C.J. (1979) Development of cell types and of regional differences in the postnatal rat epididymis. Am. J. Anat. 154, 27-56.

Tindall, D.J., Hansson, V., Sar, M., Stumpf, W.E., French, F.S. \& Nayfeh, S.N. (1974) Further studies on the accumulation and binding of androgen in rat epididymis. Endocrinology 95, 1119-1128.

Turner, T.T. (1979) On the epididymis and its function. Invest. Urol. 16, 311-321.

Voglmayr, J.K., Fairbanks, G., Jackowitz, M.A. \& Colella, J.R. (1980) Post-testicular developmental changes in the ram sperm cell surface and their relationship to luminal fluid proteins of the reproductive tract. Biol. Reprod. 22, 655-667.

Received 12 January 1982 